\title{
Urbanization on Cyprus: The View from Idalion
}

\author{
Pamela Gaber* \\ Department of Archaeology \& Anthropology, USA
}

Submission: July 11, 2018; Published: August 22, 2018

*Corresponding author: Pamela Gaber, Department of Archaeology \& Anthropology, USA, Email: gaber@lycoming.edu

\begin{abstract}
Some recent scholarship holds that most societies on Cyprus were agrarian and rural until the Late Bronze Age. Their evidence derives from coastal sites or northern settlements. Evidence has emerged that urbanization began at least in the Middle Bronze Age: a slow process of settlement agglomeration in inland Cyprus. Exploitation of copper and the beginnings of international trade led to a steady growth of settlements, trade, and industry. Inland settlements show rich growth before ca. 2000 B.C.E. A consideration of theories of urbanization and the latest evidence from excavations on Cyprus suggest a rejection of the "urban revolution" or 'exclusively north-of-the-island' approaches. Inland sites and re-examinations of older material indicate long, slow growth for the Bronze Age urbanization of the island. A dearth of excavated material from interior urban sites from the Middle and transition to the Late Bronze Ages suggests that a near-term focus on excavations in this period in the interior of the island will clarify just when the settlements became urban centers: probably c.2000 B.C.E. (Figure 1).
\end{abstract}

Keywords: Urbanization; Cyprus; Idalion; Urban revolution; Social organization; Transportation; Communication; Monumental buildings; Bureaucracies; Charter cities; Tribes; Planting; Politics; City kingdoms; Bronze Age; Landscape

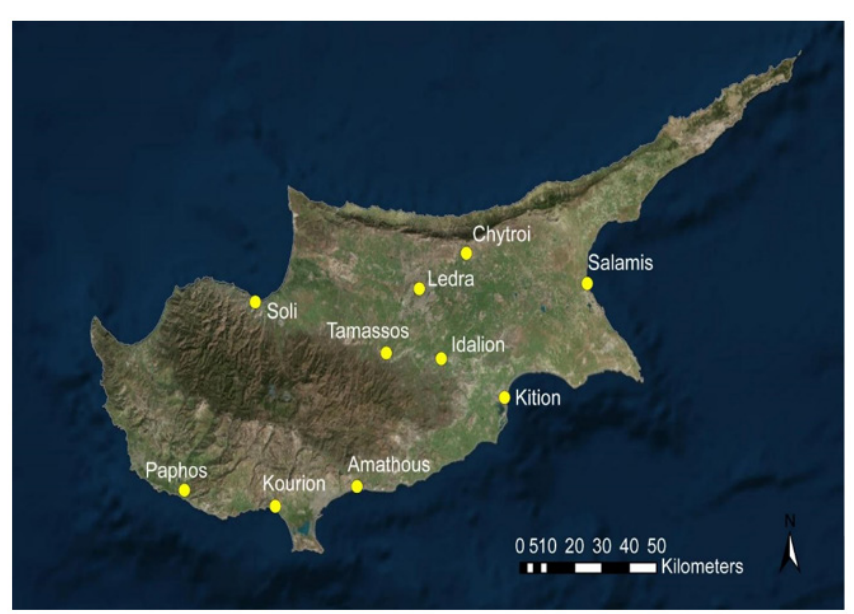

Figure 1: Cities on Cyprus in the first millennium B.C.E.

\section{Introduction: Urbanization (with Particular Reference to Cyprus)}

What is meant by "urban" centers? There have been volumes written about the development of cities since the middle of the nineteenth century. Perhaps the first modern scholar to consider the nature of urbanization was Numa Denis Fustel de Coulanges, whose The Ancient City was published in 1864 and struck a nerve in academic circles in England and France in particular. His interest was in the ancient Roman city, and his concerns were with the causes of the development of cities. "[Both] Civitas and Urbs referred to what we call a city. One is the association of families, the other the place where it takes place it was needful that the association should have been agreed on first...and the families, the curiae, and the tribes...united by one worship" [italics mine].

Social organization-families, clans, tribes-and religion were the determinants of city development for Fustel de Coulanges. For him, social structure and belief systems are the glue that holds urban centers together. Indeed, social organization and religion remain relatively constant in theories of urbanization up to the present day. Fustel de Coulanges' was the dominant view 
well into the mid-twentieth century, influencing such seminal thinkers as Emil Durkheim and Max Weber [1]. Elaborating the 'social organization and belief system' theme, Weber saw a concentration of population, interactions including surpluses involving exchange and/or trade, some form of monumental buildings, and [possibly all resulting from] autonomy of some sort as features of urbanization.

Shortly before Weber's pronouncements on the subject, in 1950, Vere Gordon Childe wrote what may be the most influential single work on the development of cities, "The Urban Revolution" [2,3]. From the point of view of a Marxist prehistorian, he outlined what he saw as the development from Neolithic agrarian societies to urban centers that were larger and denser than the previous rural settlements. He set

forth ten traits a 'city' must have to be so designated. For Childe, religion was only one among several institutions requiring or dispensing resources. He introduced the idea that "belonging" in the urban context might have been a function of location of residence, rather than kinship or tribe [4]. (Many of the 'traits' listed by Childe appear in later discussions of urbanism). One thing he noted importantly is underlined by Robin Osborne "... the formation of towns is as much about the economy as it is about politics" [5,6], or, I would add, social structure.

Colin Renfrew in 1994, asserted that, "His [Childe's] vision of change....along with his concepts of the Neolithic Revolution and the Urban Revolution, may be regarded as the first coherent analysis of the processes of change at work in prehistoric times". Michael Smith undertook a re-evaluation of Childe in 2012 and concluded that "Within this tradition of research on cultural evolution, Gordon Childe's concepts of the Neolithic and Urban Revolutions rank among the most important theoretical advances". In his later work on urbanization, Smith continues to refer to the "Urban Revolution," as Childe did [7,8]. (It should be noted that neither Childe, Renfrew, nor Smith differentiated between 'urban center' and 'city' any more than Fustel de Coulanges did a hundred years earlier.)

In fact, archaeologists have been arguing for decades about what, in fact, constitutes an urban center at all. Osborne attempted an overview of definitions of 'city' in 2005 [9]. He concludes that they generally have at least 5,000 inhabitants, are at the core of a settlement hierarchy in the vicinity and include major or monumental architecture [5]. It is difficult to support the number 5,000 specifically. There are few empirical studies that could substantiate any quantity of population as defining an urban center rather than a town or village. Indeed, early on Peter Wells stated clearly that "A distinction between towns and cities is arbitrary; both exemplify the phenomenon of urbanism" [10]. The same would seem to apply to arbitrary population figures (and, perhaps the term 'city' as well). What, after all, is the difference between a center whose population numbers 4,900 and one whose population numbers 5,100 ? Such a quantification seems unnecessary and not particularly helpful. Osborne's observation that an urban settlement should be at the core of a settlement hierarchy in the vicinity, however, is significant.

It is the character of a settlement rather than the quantity of its population that must determine whether it is an 'urban' center. It is important to note the density of its population relative to the surrounding territory. Of use here is Trigger's dichotomy between city states and territorial states. One of the ideas that long held sway was that a core settlement-or in the case of world-systems analysis, a core state-exerted control over settlements of lesser stature. For instance, "core states possess complex political structures (stratified class systems with large bureaucracies) and, by means of superior technology, exercise control over the major facilities of production transportation, and communication" [11,12].

In terms of core-periphery relationships between cities and smaller settlements, control would be extremely difficult to demonstrate in the archaeological record. This is particularly true in Cyprus when examining the limits of urban territory. Various attempts to demonstrate control have involved examination of Bronze Age forts and copper production [13]. Since two of the forts under discussion were at Dhali Kafkallia and Agios Sozomenos Glyka Vrysy, it seems more reasonable to posit their ties to Ithal/Idalion rather than far away Enkomi. If the polity at Ithal/Agios Sozomenos was producing copper or preliminarily-smelted ore for transport to coastal centers, it stands to reason that they would have need of forts to protect the caravans or transport convoys carrying their products to the coast- or their payment back again. There is no intrinsic way of knowing to whom such strong holds owed their allegiance.

It is, however, possible to demonstrate contact, even degrees of contact. For example, the demonstration of sculptural workshops in each center and finding a preponderance of works produced by them in nearby settlements strongly suggests a close economic and/or social relationship. Witness interregional networks which resulted in the receipt of goods at Amelikou Aletri from both the north coast and western portions of the island in the third millennium B.C.E. [14]. "Pottery...suggests that they were closely linked..." with those regions [15]. It is common for there to be far fewer works created in each center found in settlements at a distance from the center where the workshop was based, unless there is some other special relationship operative. Similarly, stone or clay works may be sourced chemically, and proximity (once demonstrated) is analogous to the workshop example. Control, however, implies a feature of the socio-political relationship between the core settlement and surrounding settlements that is intangible in material culture without written sources of some kind, perhaps like the kudurru found in first millennium Mesopotamia [16]. More importantly, control is not a necessary component of a core-periphery relationship between settlements [17]. (More later on the coreperiphery relationship of cities on Cyprus.) 
Currently models of urban development appear to vary by region. It does appear that urbanization on Cyprus differs from urbanization in some other regions. Some 'urbanization' models formed in the Mediterranean revolved more around social and political organization than around religion as a prime mover $[18,19]$ Urbanization in the Levant appears to have centered around walled towns as early as the Early Bronze Age [20], while close by on Cyprus, Bronze Age polities seem not to have had fortifications for the most part.

The familiar "charter cities" model accounts for many Greek colonies [21] and for the Roman castra (e.g. Boëthius 1948), both of which were situations where the parent culture was "planting" colonies and had a basic plan in mind.ii One could argue that this presents a different situation from that of original urban formation, but colonies are new urban "plantations" after all. Perhaps "charter cities" should be thought of under the rubric of "secondary city formation".

John Bintliff's social ecology model was formulated to address the creation of the Greek polis [22-24]. It is clearly social and political organization that appeal to him as formative factors. He states that living in the vicinity of a polis was most desirable for "both socio-political and economic reasons." Furthermore, involvement of citizens, at least of the hoplite and aristocratic classes, in the political as well as intense socio-cultural and ritual life of the polis, made asty residence highly desirable if not essential. Here he accords religion a role, apparently viewing it as a political and possibly an economic factor.

In an earlier treatment, Bintliff proposed a variety of models to explain why people formed urban centers. "Only a range of models...could account adequately for the complex trends observed in regional developmental trajectories. Nevertheless, it can be claimed that regional geography, combined with levels of available technology, exercised a profound influence in the medium to long-term upon the timing and intensity of regional demographic and economic growth." This multi-model approach, combined as it was for Bintliff with a regionalist approach, seems the most promising route to follow in understanding the development of urbanism in Cyprus. Included in Bintliff's catalog of useful models was the "core-periphery" model, perhaps the most ubiquitous in late twentieth century scholarship [25,26]. The usual explanation describes a coalescing of a population center with a hierarchy of smaller settlements around it (Figure 2).

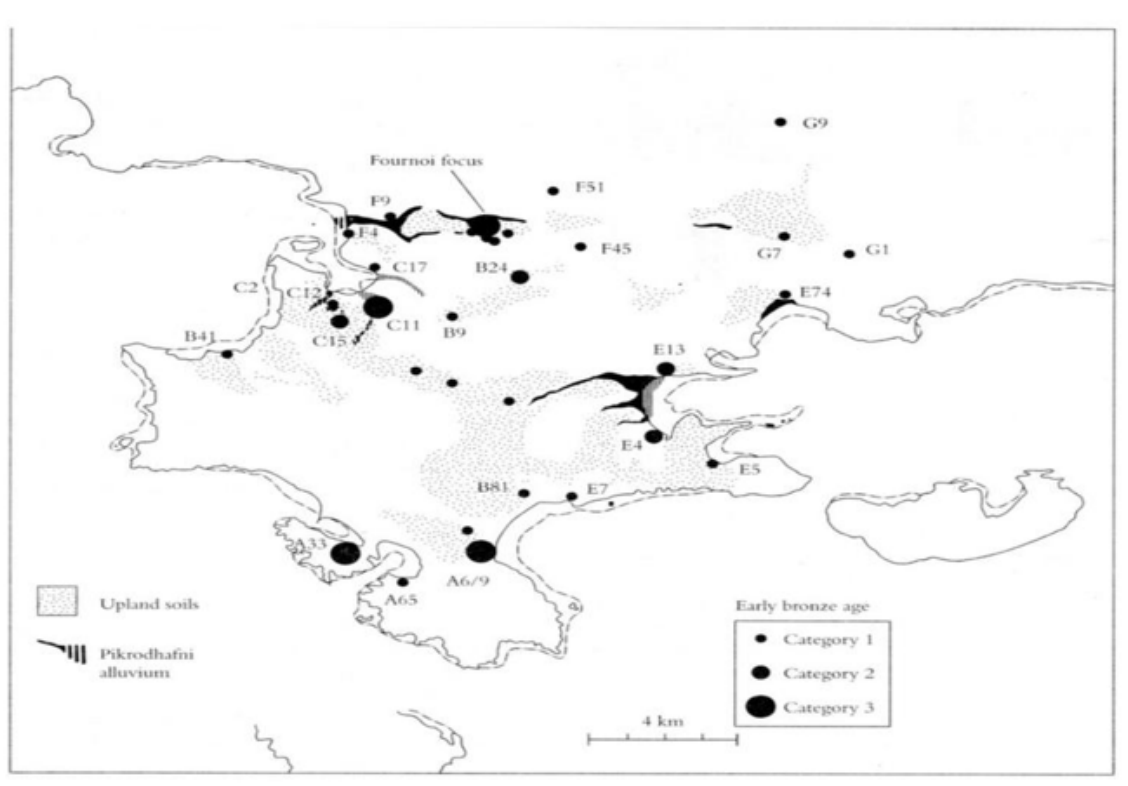

Figure 2: Settlement Hierarchy/ Site Catchment Analysis.

\section{Cities on Cyprus}

In recent years this model has been greatly refined. An influential article by David Rupp posited boundaries for the "citykingdoms" of ancient Cyprus [27]. The discussion of boundaries was predicated upon the mention in Assyrian texts that Cyprus had several "city kingdoms". Rupp inferred from those references that each city-kingdom must have had a fixed boundary, which would have impacted on the nature of such cities and their formation. (Figure 3). The implication here is that the peripheral settlements of all sizes-towns, rural villages, or hamlets-would have been clearly divided between the urban centers in such a way that their territories were recognizably different one from another. Rupp was so certain about this that he had two separate maps detailing the fixed boundaries of Cypro-Archaic I vs. CyproArchaic II city-kingdoms on Cyprus Some scholars continue to refer to these models [28]. 


\section{Global Journal of Archaeology \& Anthropology}

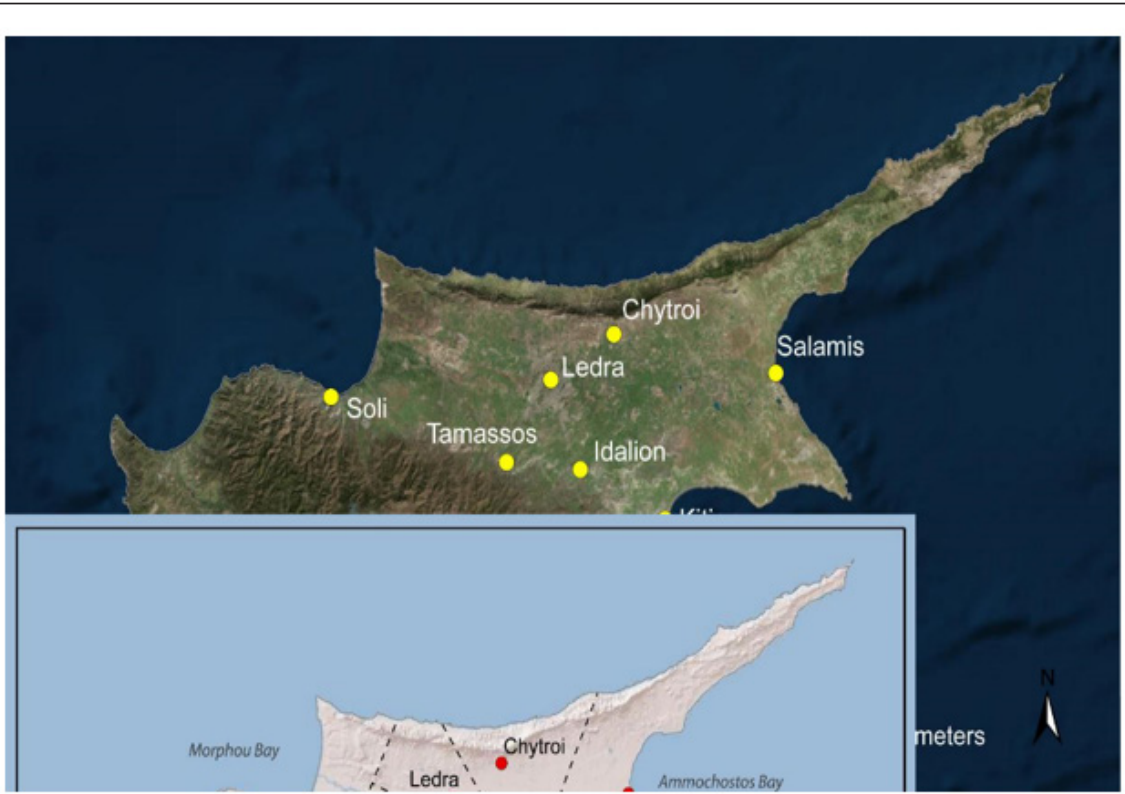

Figure 3: City-kingdom 'boundaries.'

Monica Smith points out that, "A landscape perspective on urbanism addresses the mutually implicated ritual, political, economic, and social uses of urban centers and their surroundings in both the past and the present. A landscape approach also makes use of archaeology not merely defined as the study of antiquity but broadly conceptualized as the analysis of material culture and the human modification of spaces...". Approached in this manner, an examination of urbanism on Cyprus will appear less rigid than Rupp's maps imply. It is this landscape approach that is advocated here.

In a 2013 article, Sabine Fourrier produced an intricate and persuasive case for much more fluid boundaries between urban territories than those advocated by Rupp and his followers. She demonstrates that these more fluid boundaries are discernible through an examination of rural sanctuaries. Her discussion differentiates urban, peri-urban, and rural sanctuaries in detail [29]. With reference to putative boundaries of city-kingdoms she says:

The distribution of extra-urban sanctuaries structures the kingdoms' landscapes on various levels...on the presumed boundaries between kingdoms' territories, as in the case of the Arsos sanctuary...and of the Vavla-Kapsales sanctuary... Other sanctuaries mark different kinds of boundaries, between differentiated spaces of the same kingdom, and especially between the cityscape and the rural landscape. The case of the peri-urban sanctuaries is particularly interesting...Located on the undefined zone that separates the city from the surrounding land, they mark the limit as well as the passage from the (semirural) suburbs to the city [29,30] (Figure 4).

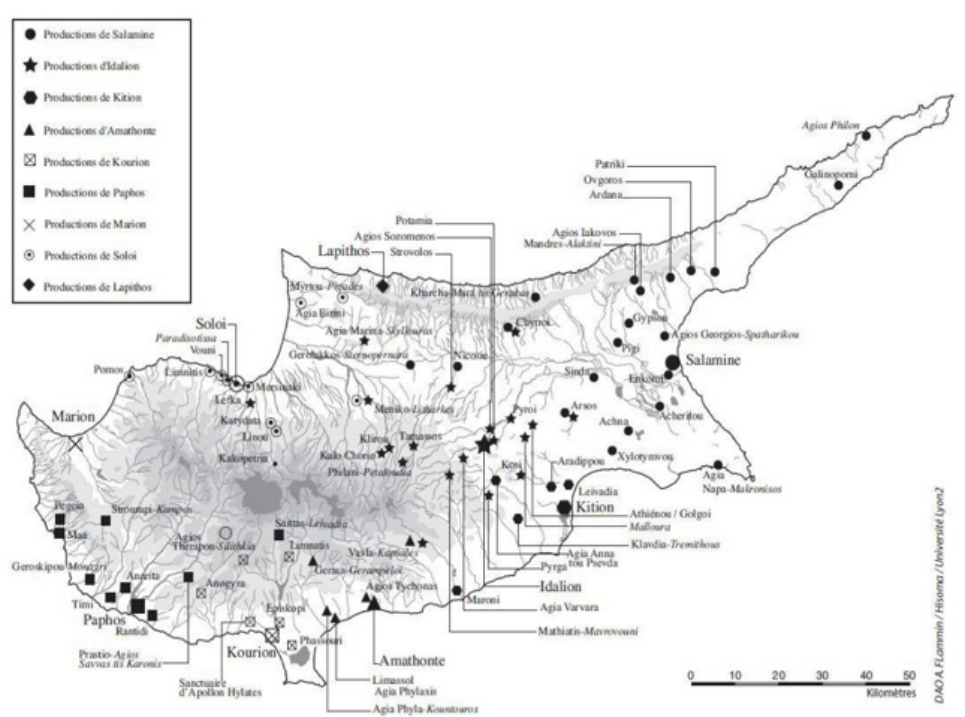

Figure 4: Distribution of Terracottas in the Archaic period illustrating rural sanctuaries. 


\section{Global Journal of Archaeology \& Anthropology}

This is a far more sophisticated understanding of the fluidity of the boundaries between what might be termed 'spheres of influence' of the urban centers of first millennium B.C.E. Cyprus, or indeed, a way of characterizing what is referred to above as 'liminal zones.' Fourrier also incorporates the relationship of settlements to their landscape. However, her approach outlines an entirely etic representation, (that is, viewed from outside) and therefore it is somewhat counter-intuitive (Figure 5).

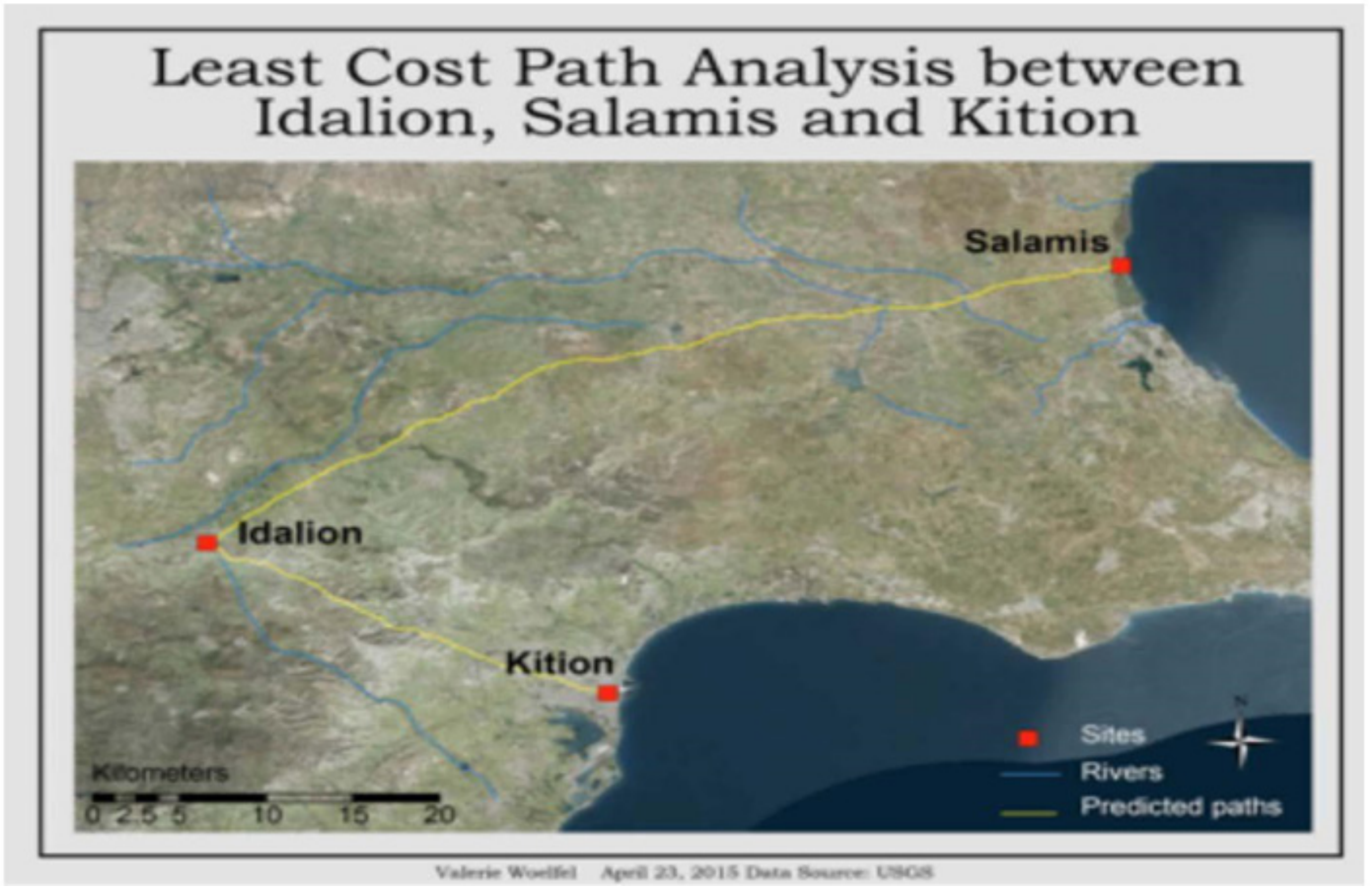

Figure 5: Least Cost Paths to east coast and south coast based on slope using 30 meter ASTER imagery.

An emic vision (viewed from inside the living culture) would not see the people of Archaic and Classical Cyprus perceiving themselves as moving from urban territory to urban territory when they were participating in activities in one rural or semirural shrine or another. Rather, they would go to one or other of these sanctuaries for one or more of a variety of reasons:

a. A given day or time of year was deemed the "appropriate" time to participate at a given temenos. (A modern analogy might be a saint's day, when worshippers go to the church dedicated to that saint to participate in rituals specific to that saint.)

b. Their daily activities took them to a given region on the day when certain rituals needed to be observed, and they then took their offerings and observance to the sanctuary nearest to the area where their activities were taking place.

c. Their personal abode or lands lay in the region adjacent to a given sanctuary, thus making it more convenient for them to participate in rituals in that sacred space.

d. Their personal abode or lands lay in the region adjacent to a given sanctuary, thus making it personally significant to them and their home and/or lands.

e. An event in their personal lives was associated with a specific locality or sanctuary, thus giving that sacred space personal significance to them.

There might be any number of other, similar reasons for members of first millennium B.C.E. communities on Cyprus to participate in rituals in a given sanctuary, some of which were undoubtedly influenced by the landscape. None of these reasons for participation in any way militates against the etic points about boundaries outlined by Fourrier. In addition, elites of urban centers might easily find it expedient to demonstrate their interest in and potential presence in these liminal zones, giving generous-or opulent-votive gifts as highly visible evidence of their interests (Figure 6). Fourrier's view was recently further detailed by Giorgos Papantoniou in 2013. He investigates “... the relationship between Iron Age sanctuaries and territorial claims...the study of Cypriot sacred landscapes in the longue durée-their transformations and their possible change of meanings-reinforces Fourrier's interpretation that extra-urban sanctuaries played an important role in the political setting of the city-kingdoms" [31]. His methodology adds a meticulous environmental examination to the previously articulated sacred landscape approach sketched by Fourrier. Together these are new ways to view the 'periphery' portion of the settlement hierarchy model in Cyprus. They make the social and cultural component of ritual and cult central to defining the outliers of urban spheres of influence (Figure 7). 


\section{Global Journal of Archaeology \& Anthropology}

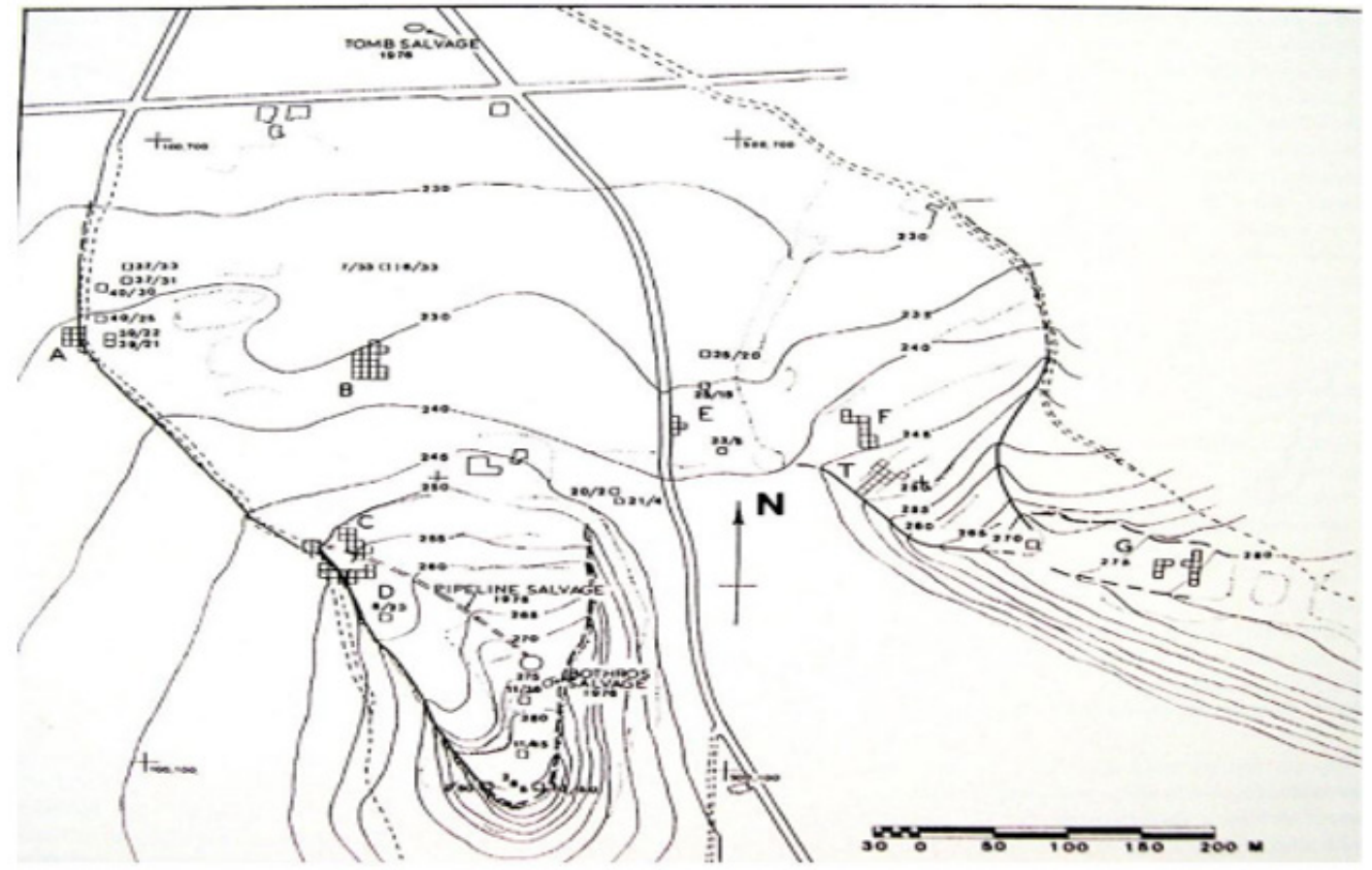

Figure 6: Excavation fields at Idalion: (A) City Wall. (B) Lower City North, (C) Terrace of the West Acropolis, Ambelleri, (D) Hellenistic copper working installation, (E) Lower City East industrial installations, (F) Hellenistic Administrative Center, $(G)$ sanctuary of the Great Goddess, (H) City Sanctuary, Lower City South, (T) Adonis Temenos.

Figure 6. Deep sounding in the Lower City North (B) industrial area.

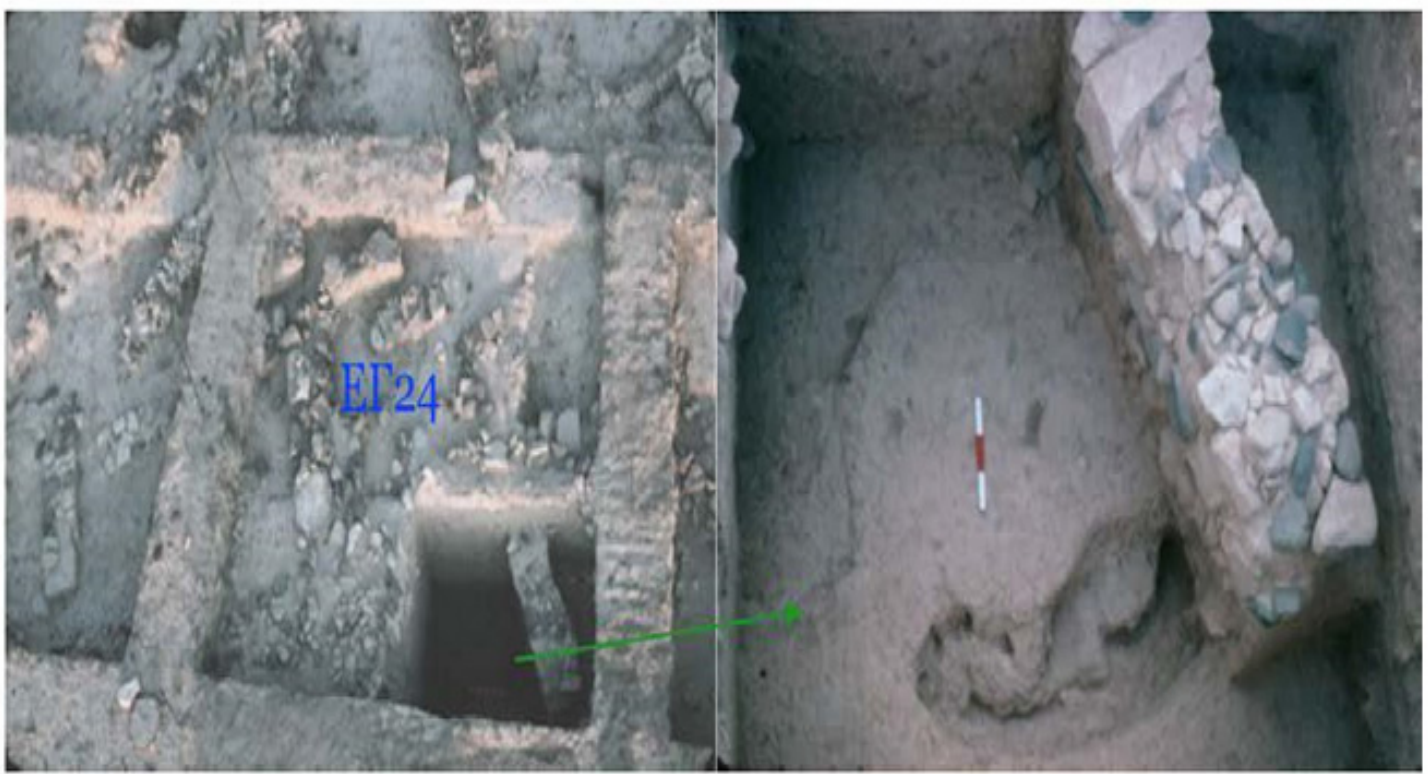

Figure 7: Deep sounding in the Lower City North (B) industrial area.

Both Fourrier and Papantoniou imply-and sometimes state directly-that city-kingdoms on Cyprus founded rural sanctuaries specifically to mark their boundaries [32]. It seems much more "organic" to understand rural sanctuaries as having developed naturally in response to rural residents' desire to participate in spiritual and ritual practice close to home. Then, once a given rural sanctuary was well-established on the periphery of one city-kingdom or another, a ruler might see it as politically 
beneficial to make a conspicuous dedication there (as above). There is no evidence to date of any rural sanctuary being a royal foundation. Once again, an emic interpretation seems to fit the evidence best. This emic approach appears to be what motivated George Cowgill who said:

I vaguely define a city as a permanent settlement within the larger territory occupied by a society considered home by a significant number of residents whose activities, roles, practices, experiences, identities, and attitudes differ significantly from those of other members of the society who identify most closely with "rural" lands outside such settlements lands ers of the so catchment areas, but only cities have hinterlands. Inhabitants of cities may have interests and even additional dwellings in th countryside, and rural people may visit cities for many purposes. The distinction is, above all, one of identities [emphasis mine]. His notion of identities and relationship to the hinterland seems to express succinctly the approaches of Fourrier, Papantoniou, and that advocated here.

An example of the relationship of place of residence and activity to religious practice is evident in a pre-kingdom period on what would become the west acropolis of Idalion in the Iron Age where there is evidence of industrial activity [33]. During recent excavations in the sacred grove on the hill, Mouti tou Arvilli (later the east acropolis of Idalion), Late Bronze Age installations were found on bedrock (Figure 8). This seems to imply that those who worked nearby worshipped close to their workplace. Indeed, Late Bronze Age tombs in the area have been known for decades [34-36]. The phenomenon of a small center of worship founded near a working settlement in the Late Bronze Age lends weight to the suggestion that at least some rural sanctuaries may have been founded for the convenience of local worshippers, perhaps by the worshippers themselves.

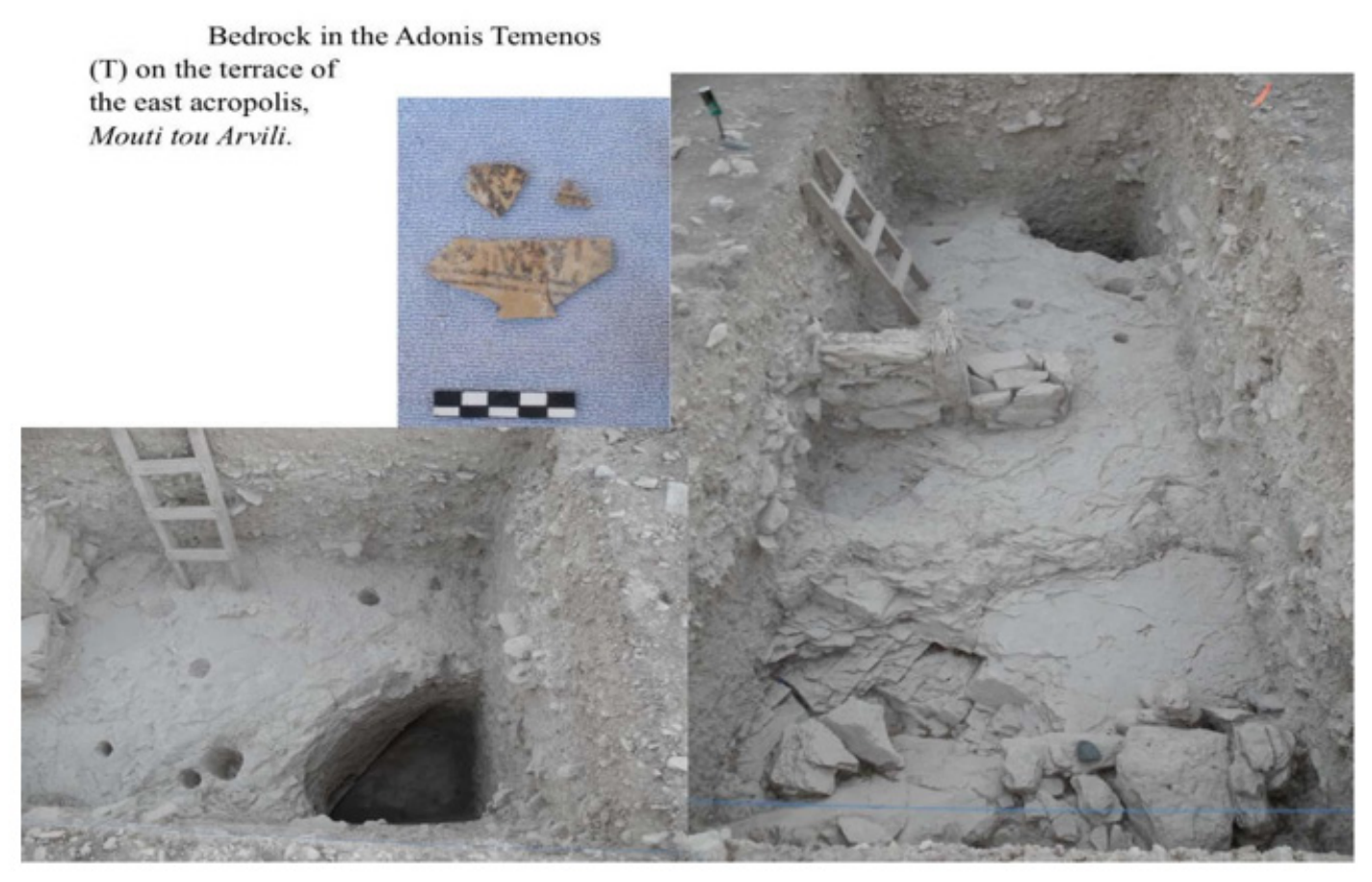

Figure 8: Bedrock in the Adonis Temenos $(\mathrm{T})$ on the terrace of the east acropolis, Mouti tou Arvili.

These sacred landscape discussions go some way toward examining the relationships of urban centers with their hinterlands. Large settlements in second millennium B.C.E. Cyprus do appear to have socio-economic relationships with smaller settlements nearby. There is, however, no reason to suggest that they control those smaller settlement. There could easily be an economic exchange that benefitted both settlements. One village could produce agricultural products they exchanged with the larger settlement(s) or other villages. Another might have been working copper. A copper-producing settlement might exchange their copper primarily with the large center, or with other small settlements (Figure 6).
In fact, it is quite likely that any one agricultural settlement had economic relations with more than one large center. There is no reason to suppose that those near the outer regions of the sphere of influence of one urban area may not have related to another center, perhaps of similar distance. Just as it is quite likely that inhabitants in the liminal regions frequented more than one rural sanctuary, it is equally likely that they traded with more than one village, town, or large, urban settlement. In attempting to define urban centers, there is no need to assume control of outlying settlements.

It is also important to remain aware that urbanism does not necessarily equal state formation. There are, however, analogies 
to certain phenomena visible in state formation processes and to the development of urban settlements. One such is secondary state formation. For instance, according to Alex Joffe, "Ethnic states" are not types or stages in an evolutionary scheme. Rather they are novel and historically contingent political systems that appear in the Levant during the first millennium B.C.E. thanks to the confluence of several factors, not least of all...the longstanding city-state system [37].

In fact, looking at this "state formation analogy," a recent study of the development of the city-states on Crete has suggested rather a complex secondary state formation model for them. "(2000-1680 B.C.E.) As the Minoan palatial societies developed, they were integrated into a network of interaction that extended from Anatolia and the Near East, including Cyprus and Egypt. In world-systems jargon, they became a periphery of the Near Eastern and Egyptian core states" [38].

It is precisely this network we are examining here. Given the appearance of copper from Cyprus early in the second millennium in both Crete and southern Jordan, it seems clear that these networks were firmly established before or right around 2000 B.C.E. (Figure 7). [39,40] Figure 6. For third millennium production see Knapp [41,42]. It is reasonable to suggest similar growth of centers on

Cyprus to those on Crete 'peripheral' to the great trade axes of the ancient Near East; particularly if these Cypriot centers were providing copper to those outside the island. Kassianidou \& Muhly [43] report that $18 \%$ of the copper found on Crete by the 18th century B.C.E. came from Cyprus. This network must have been firmly established by then. (It must be noted however, that the form that the polities took on Cyprus appears to be far different from that developed on Crete.)

The recent work of Michael Homan has demonstrated that the copper used in Mesopotamia and Egypt at the turn of the second millennium B.C.E. underwent a profound shift. According to Homan, copper in Mesopotamia was recorded as coming from Alashiya (Cyprus), Magan (Oman), and Dilmun (Bahrain), from ca. 2000 B.C.E. until 1745 B.C. E. with an increasing appearance of Alashiya in the inscriptions, and a decrease in the appearance of the other two. By 1745, Magan and Dilmun disappear altogether as sources for copper recorded in inscriptions, and all of Mesopotamia's recorded copper imports come from Alashiya after that date. Clearly then, Mesopotamia is importing copper from Cyprus by 2000 B.C.E (and only from Cyprus after the 18th century B.C.E.). Similarly, in Egypt, the tomb of Khnum Hotep III in the low chronology J Allen [44] records the transport of oxhide ingots at the very beginning of the second millennium.

\section{The Relationship of Copper Exploitation to the} Development of Urban Centers on Cyprus

Views are changing in our understanding of the history of Cyprus during the Bronze and Early Iron Ages. Evidence is accumulating against the long-held view of the nature of Middle
Cypriot settlement on the island. Previously it was believed that the entire island was rural with an agrarian economy until the Late Bronze Age, when a sudden burst of interactions with outsiders led to a volcanic growth of the copper trade and a rapid development of urban polities. A. Satraki, for instance, states that "...the 1400-year-long era from the beginning of the Late Bronze Age to the end of the Cypro-Classical period is sharply distinguished from the preceding stateless and pre-urban Early and Middle Bronze Age..." [45].

This narrative of the development of Cypriot urbanism depends in large part upon the pre-historic copper trade. Maria Iacovou set forth what she considers to be the sine qua non of early Cypriot 'city' formation: "The economic model that gave substance and wealth to a (diminishing) number of states for a greater or lesser period...did not require control of the entire island by any one of them. Nonetheless, it appears to have been dependent on a minimum requirement: control over a geographically unified territory that had (a) copper sources, (b) agricultural wealth, and (c) access to a port of export". This model has been repeated elsewhere since that publication, and certainly seems sensible.

The problem with this analysis is the term "control over" as has been mentioned. Too often, understanding of the territory under the influence of a given polity suffers from a Eurocentric vision (conscious or subconscious) of 'nation states,' or at least the kind of strict boundary adherence implied by the Mesopotamian kudurru, for example. It seems evident that no such firm, fixed boundaries existed in the early history of polities on Cyprus. Rather than speak of 'boundaries,' scholars do better to speak in terms of 'liminal zones', as above. If it can be demonstrated that in these early periods the people exploiting copper sources could utilize deep deposits of ore and stay in one place for a considerable length of time where they could develop continuity of settlement, then evidence for the picture of their settlement pattern changes.

The recent publication of Ambelikou Aletri: Metallurgy and Pottery Production in Middle Bronze Age Cyprus has added to this mounting evidence [46]. It is significant that the metallurgical industry at Ambelikou clearly indicates the exploitation of deep, sulfide ores over a prolonged period by a group settled at the same site. In addition, "There is also little to indicate that the community at Aletri was either socially or physically isolated... Pottery...suggests that they were closely linked with a larger regional settlement or settlements in the Karkotis River valley; and the presence of imported vessels suggests that they were integrated into interregional networks which resulted in the receipt of goods from both the north coast and western portions of the island". An image emerges of a bustling, copper-producing, trading community with ties to several other settlements and even other regions. The stability of settlement will have allowed for growth of the population in the same place over time.

Thus, we see a picture of a small, but growing network of copper exploiting settlements and an exchange network active in 
the northwestern portion of the island very early. It is reasonable to suggest that such networks existed elsewhere on the island as well. Iacovou appears to acknowledge this possibility when she says, “...Cypriot archaeology has only recently begun to consider that the copper-based economic model was not a monopoly of the Late Cypriot polities", although she refers to the long Apliki exploitation of deep source copper as "pre-industrial" [47,48]. It is also vital to remember that while copper may have been central to the developing economy, there were other industries active at the time, like the brewing operations at Kissonerga Skalia [49] and others.

As has been mentioned, Cypriot copper was reaching Crete and the Levant by the 19th century B.C.E. and copper exploitation on Cyprus can be demonstrated already late in the third millennium B.C.E. [50-52]. For this to be the case, a long, slow development must have begun some time perhaps by the middle or the last third of the third millennium B.C.E. This gradual development of settlements across the island can be understood to illustrate the growth of copper exploitation and exchange as well as other industries through the late third and beginning of the second millennium B.C.E. According to Vasiliki Kassianidou, "the number of copper artefacts significantly increases in the ...ECY 3-ECY 5, which correspond to the earliest phase of the Bronze Age, probably because by this time copper is smelted from its ores and...there is...more metal available" [53]. The suggestion here is that there is a slow growth of copper extraction and trade that gradually built up, with a corresponding growth in the associated settlements. This runs counter to the "urban revolution" model still in vogue among some on Cyprus. It does appear to accord best with the growing evidence of copper exploitation and trade in the Middle Bronze Age [54,55].

In the Middle Cypriot (Middle Bronze) period for Kassianidou the picture is different from that of the Early Cypriot. She lists several sites of importance. More metal appears in burials at Bellapais-Vounous and Lapithos-Vrisi tou Barba, as well as some at the sites of Marki-Alonia, Sotira-Kaminoudhia, KalavassosPanayia Church. Thus, a number of settlement sites attest to this upsurge in copper production, as well as other industrial endeavors. An example of long development is provided by Kissonerga Skalia, where again development is evident from Early Cypriot-Late Cypriot I. What these sites attest to is increasing organized industrial activity (although not copper working specifically in this instance, but elaborate brewing operations) toward the latter stages of the Middle Cypriot period. In reference to the copper industry, Jennifer Webb says, "Mining settlements like that at Ambelikou probably had a long history on the island by the MC I. Similar communities of skilled miners and smelters integrated into communication networks managed by regional centres or coastal outlets may be envisaged also for the Philia period...the linkage to a larger extra-regional entity or entities-may be the key to understanding the internal dynamics of the 'copper trade' in both the Philia EC and MC periods." She goes on to list sites producing copper: Ambelikou, Katydhata, Marki; Alambra MCII; Pyrgos, Episkopi Phaneromeni, Paramali Pharkonia and Politiko Troullia casting and refining (Figure 9).

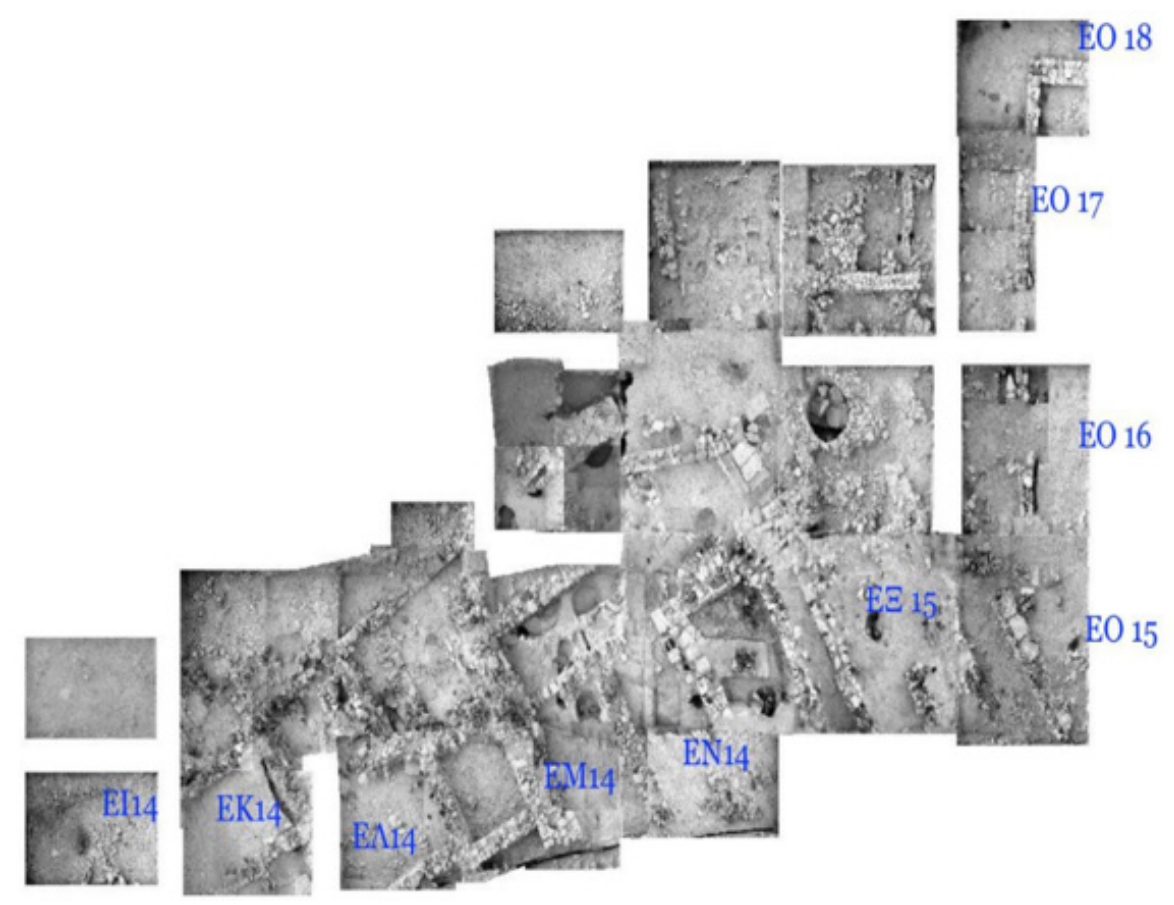

Figure 9: Rectified photogrammetric aerial view of excavations in the Lower City South (H), the 'City Sanctuary' of Idalion. [Grid squares labeled] 
In short, it appears communities on Cyprus were certainly capable of exploiting and exporting copper by the beginning of the second millennium B.C.E. This picture runs directly counter to the rural, purely-agrarian-before-the-Late-Bronze model [56]. It appears there were long-standing settlements gradually building up industrial activity in brewing, smelting and pottery production. These settlements were trading with one another on the island and in some cases with foreign consumers in Crete and the Levant as demonstrated by the Cypriot copper found there. Already in 1996, E. Peltenburg posited state formation during the Middle Cyptiot III period.

Such a growth over the longue durée could very well have developed into a network of what might be termed urban centers before the Late Bronze Age. Where would one look for such centers? Some of these developing centers producing and trading copper, especially in the inland heart of the island (possibly insulated from the ructions along the coast), continued without a break into the Iron Age and throughout the first millennium B.C.E. (The center that became Idalion was one such; see contra Knapp who sees such development only in the northern part of the island) (Figure 10). This uninterrupted development-possibly leading to the emergence of cities-can be demonstrated in the archaeological record and is at odds with some current views. Witness Iacovou: "Early Iron Age politicoeconomic territories were formed during, and as a result of, the power vacuum that followed the crisis years and the dissolution of the Late Bronze Age states' economic system" $[57,58]$.

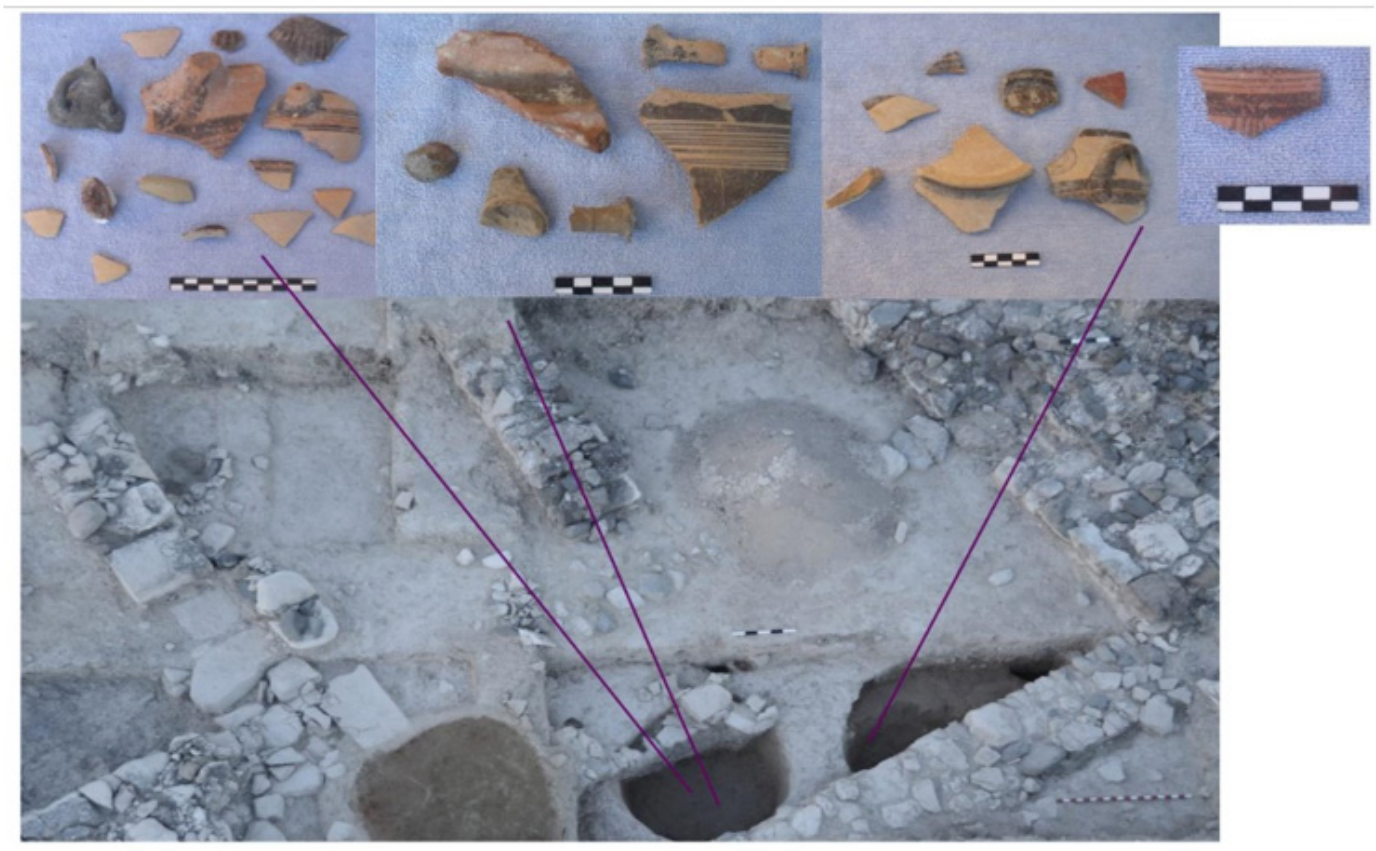

Figure 10: Deep soundings in pits in the City Sanctuary $(H)$ below the west acropolis, Ambelleri.

In examining previous discussions attributing the rise of urbanism on Cyprus to Aegean colonists, however, Iacovou in her 2012 tribute to Nicolas Coldstream was interested in fleshing out Coldstream's image of Aegean migrants (as opposed to colonizers). In so doing, she characterized Cyprus toward the end of the Late Bronze Age as having a "robust environment" especially with regard to the "coastal centres of Late Bronze Age Cyprus" [59]. The use of "robust" in this context appears to refer to an energetic environment of production and trade. It is most likely that the coastal centers were "robust" because they received a substantial supply of copper and other products from inland centers of production and refining, like the predecessors of Tamassos and Idalion (cf. above discussion of Middle Cypriot industry). These inland centers may not have experienced any interruption in their prosperity and settlement development like that experienced by coastal centers in the Late Bronze Age. Certainly, Idalion did not. In addition, there is no need to see the central settlements controlling the coastal trading sites, or vice versa as already stated.

Cities are universally acknowledged to have existed on Cyprus in the first millennium B.C.E. Assyrian texts are most often cited as evidence. That of Sargon seems to commemorate a military action undertaken on behalf of Sargon's Tyrian allies, while the inscriptions of Esarhaddon and Assurbanipal refer directly to ten kings of Cyprus whose cities paid tribute to those kings: Idalion, Chytroi, Soloi, Paphos, Salamis, Kourion, Tamassos, New Town (most likely Kition), Ledrai, and "Nuria" [60].

There has been disagreement about when those cities emergedx, but some form of urban polity is likely to have existed in the time of the Medinet Habu inscription. The inscription refers to places on Cyprus, specifically Salamaski (Salamis), Kathian (Kition), Aimar (Marion), Sali (Soli), Ithal (Idalion), (M) 
aquas (Akamas), Kerena (Kerynia) [61,62]. The determinatives for "city" are not present, but neither are those for "people." It seems, therefore, that the list refers to localities known in the $12^{\text {th }}$ century B.C.E. Written evidence is not much help, therefore. It is archaeology that may illuminate the question of when cities emerged.

\section{Idalion}

The best example of such a site is Idalion and its predecessor at Agios Sozomenos. In addition to proximity to copper sources at Alambra and Ayia Varvara (Alambra is actually in sight of Agios Sozomenos), the situation of Agios Sozomenos is ideal for agriculture and access to coastal sites (Figure 5).

It is the access to coastal sites that is most important for the role of the site in the probable Middle Bronze Age copper trade as just described. If the Middle Cypriot copper production process is similar to that in the first millennium B.C.E. (admittedly a speculative assumption), Agios Sozomenos has the ideal features. It is a site near enough to the mines where the primary smelting process would have occurred-and near enough to the mines for the product of that primary process to be carted to Agios Sozomenos for finishing and preparation for shipment $[63,64]$. Later in the first millennium B.C.E., there were mines at Almyras in the vicinity of Alambra (and Ayia Varvara), an area within the gift of "the King and people of Idalion" by the fifth century B.C.E. [65]. It is quite possible that there were nearby mines in the area much earlier, although of course this is speculation. It is a reasonable working hypothesis, however, as to how an important city came to grow in this location.

Once the processing of copper and/or the production of ingots was complete, it was necessary to have access to the coasts for trade abroad to be practical. There are two clear avenues to the coasts: first is the valley of the Yialias River, which leads out to the east coast at what was in the Late Bronze Age Enkomi, then later, in the first millennium B.C.E. Salamis, and today Famagusta. The second route is the road to the south through the pass in the hills that led to the urban center in the Late Bronze Age at what is now Hala Sultan Tekke, then later from the $12^{\text {th }}$ century B.C.E. onward to Kition, and today to Larnaca. In fact, Agios Sozomenos faces the junction of these two routes (a place where the Romans later built their road to the south coast). Soundings carried out by a French team under the direction of Selwyn Lecuyer and Benoit Devillers, published in 2004, demonstrated that a substantial settlement dating from the Early Middle Bronze through the Cypro-Geometric periods existed in that location in Agios Sozomenos [66]. More recently, excavations by the Department of Antiquities of Cyprus under the direction of Despo Pilides have early indications of a Middle Bronze age settlement.

The route to the east following the Yialias River joins the Pedheios River (on which ancient Ledra was situated-the predecessor of modern Nicosia) approximately halfway to the coast. At the eastern end of the combined rivers is Ammochostos
Bay. Certainly, important in the Late Bronze Age, there are those who believe that Enkomi, the paramount trading city on the Bay, may have somehow controlled copper production on the island. As has been stated above, control is extremely difficult to demonstrate in the archaeological record. It seems more likely to suggest that inland copper producing centers decided with coastal cities to trade copper with them (e.g. Knapp 2013a: 406 and refs). This could easily have taken the forms of both ingots and products of initial smelting that would still require refinement at Enkomi itself, thus accounting for the evidence of copper production at Enkomi [67]. Enkomi and others of the coastal centers would then be set to trade abroad (Figure 9).

More telling perhaps is the trajectory of Middle Bronze Age copper producing centers in the central region of the island, like Marki Alonia and others. Webb states that "at some time in the 19th century BC Marki was abandoned." She suggests that: community of 400 people might not have been able to withstand the stress placed on these systems by diminishing resources, prompting settlement fissioning or relocation. This site-specific scenario may have been linked in ways which are not yet clear with the development in the late Middle Bronze Age of settlement at Agios Sozomenos, $12 \mathrm{~km}$ downstream from Marki near the confluence of the Alykos and Yialias Rivers. This area became the focus of a large town in the Late Bronze Age, forming a key node in a site hierarchy linking agricultural, mining and other sites to the developing centres on the east and south coasts.

This inability to sustain the Marki Alonia population may have been exacerbated by the climate stress event noted at ca. 4200 B.P. in the Levant $[68,69]$. There are some sites on Cyprus like Prastio Mesorotsos in the Dhiarizos River valley that experienced no interruption at this time. However, the Dhiarizos River is a fast-flowing, perennial mountain stream that even today produces $20 \%$ of the water of Cyprus annually. People settled on its banks probably did not experience the drought as severely as people living on the chert ridge that divides the pillow lavas of the Troodos mountain foothills from the chalky limestone lowlands of the Mesaoria Plain. It is significant that, as Webb states, the settlement at Agios Sozomenos grew near where the Alykos tributary meets the Yialias River. Such a wellwatered position would have provided what the upland sites like Marki, or, indeed, Reximon and Spanashis further up the Alykos valley, could not: continuous water supply for agriculture and industry.

Since a center like Agios Sozomenos would have had access to the south coast as well as the east coast, it seems logical to suggest that those who traded from there traded in both directions. Why not? Using the principle of Ockham's razor, the simplest explanation that accounts for the known data is the most likely. In fact, it is possible to posit that copper producing settlements, perhaps in Alambra and Politico, traded their copper with nearby settlements like Agios Sozomenos and the predecessor of Tamassos, where people would have been able to work with economies of scale, making it more practical for 
the larger towns to deal in large quantities of product than the smaller settlements near the mining sites (Figure 11). Then these burgeoning centers would trade with the coastal regions. In the case of Agios Sozomenos these would be the east coast and the south coast. By the Late Bronze Age, these sites would be the cities at Hala Sultan Tekke and Enkomi.

The recent work of Benoit Devillers and Michael Brown has demonstrated that the Middle Cypriot predecessor of Enkomi was likely to be at Kalopsidha on geomorphological grounds.
Pre-dating Enkomi, in the Middle Cypriot period, the site of Kalopsida would have been on the bayn the Middle Cypriot period, the site of Kalopsida wYialias River debouched into the bay. It is likely that the earliest east coast trading settlement would have been there [70]. It should be noted that the coastal centers were the ones trading abroad, and those would be the ones of which the rest of the world was aware (although the Medinet Habu inscription implies knowledge of inland centers as well, though that is a Late Bronze Age reference) (Figure 11).

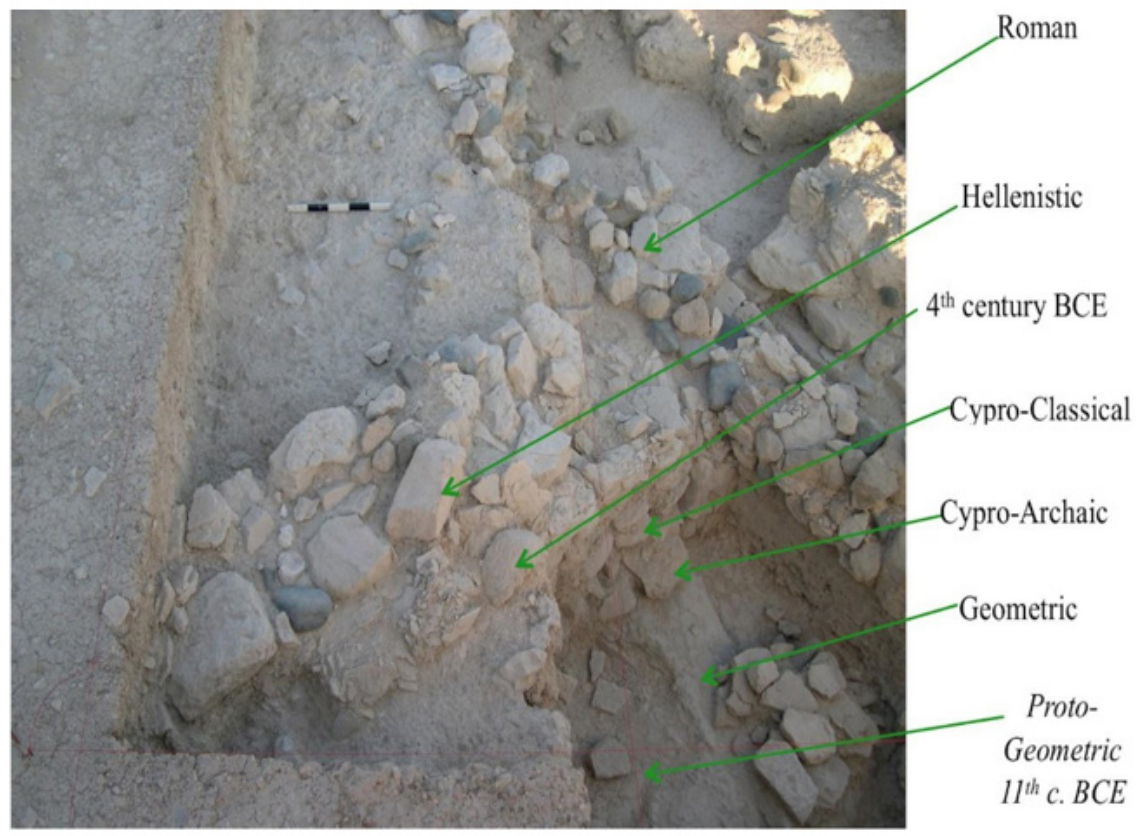

Figure 11: Deep sounding in western grid square EK15 in the City Sanctuary (H), showing continuous use from ca. 1050 B.C.E. through to the first century C.E.

Excavations at Middle Cypriot Alambra indicate clear evidence of copper working. The new excavations at Agios Sozomenos are too new for excavation results to reveal whether there was copper working there. Early indications do indicate ceramic work, at least in the Late Bronze Age there [71]. However, samplings taken in 2004 indicate that there was substantial activity at Agios Sozomenos right through to the Cypro-Geometric (or at least the Proto-Geometric) period without a visible break. It is significant that this ceramic sequence overlaps for perhaps two to three hundred years, with the settlement on the south side of the Yialias River, later Idalion, which, in its Iron Age identity is acknowledged by all to be a 'city.' In contrast, there is ample evidence from Idalion. The site has been known since the 1850s. Excavations have continued there sporadically since. The results of the most recent Cypriot and American excavations have much to contribute to a discussion of urbanism (Figure 6).

In 1995, 1996, and 1997 the Department of Antiquities of Cyprus excavated an industrial area on the terrace of the West Acropolis, Ambelleri, under the direction of Dr. Maria Hadjicosti.
They found what was most likely a pithos factory dating from the LCIIA-LCIIIB. They also found indications that the occupation in the area extended through the Geometric period. In 2004-2006 the Lycoming College Expedition to Idalion under the direction of Pamela Gaber continued working in the Lower City North industrial area of the town where they uncovered a work area that involved high use of water (several wells), three settling tanks cut out of the virgin marl of the area, and, in a deep sounding, evidence of continuous, uninterrupted work of some kind, going on in the same way repeatedly, from the Late Bronze Age to the Hellenistic period [72-76]. Several tombs dating to the Late Cypriot period have been known in the area for decades. All in all, there is enough evidence now to suggest that, although the main urban center probably remained on the north side of the River Yialias at Agios Sozomenos during the Late Cypriot period, industrial and burial activities seem to have been practiced on the southern side of the river increasingly from the Late Cypriot period onward. (Figure 7) In addition, it is clear now that there was at least one worship center active by ca. 1100 B.C.E. Figure 8 on the terrace of the east acropolis, Mouti tou Arvilli, probably to serve that population. 


\section{The "Overlap"}

It is significant that in two of the sanctuaries excavated by the Lycoming College Expedition, foundation levels in the 12th century have been reached. This accords with all the views of urbanization reviewed above, suggesting that when there was a substantial center of industrial activity established in what would later become Idalion, the people involved created significant religious installations for themselves. This enabled them to actualize a complete living experience in this newer place of settlement. Both these sanctuaries exhibit continuous, uninterrupted use from the end of the second millennium B.C.E. through the Roman period.xv Throughout the Late Cypriot and Proto-Geometric periods (and possibly into the Geometric period) the occupation at Agios Sozomenos continued, and may well have been the primary settlement area, perhaps urban already.

By the ninth century B.C.E. a substantial defensive installation was constructed on the summit of the West Acropolis, Ambelleri, the structures identified by Gjerstad et al. as a "fortified stronghold". The development of the Phoenician settlement at Kition on the south coast may have been the impetus for the need to fortify the work areas and habitations at Idalion [77]. Certainly, by later in the first millennium B.C.E. the inhabitants of Kition were anxious to capture the copper-processing centers of Idalion \& Tamassos [78]. The bronze tablet from the West Acropolis at Idalion bears testimony to one unsuccessful attempt on the part of the Kitians to take over Idalion. It is reasonable to suggest that the same reason accounted for the first evidence of fortification at Idalion, founded in the ninth century B.C.E. on the promontory facing the approach to the site from the southern coast road- the road to Kition. That is, the Phoenicians settled at Kition must already have been coveting the wealth of the cityprobably the copper processing. Thus, it would have been the threat from the south against which the stronghold was built to strengthen Idalion.

In fact, nothing of the site of Idalion itself is visible from this stronghold. Only the southern approaches, the roads and passes through the hills, can be seen from atop this acropolis (although Agios Sozomenos is visible from there). This is the earliest evidence of any fortification anywhere on the site, and it did not extend beyond the promontory overlooking the southern approach roads. It would seem, therefore, that there was not a perceived need for defensive structures before that time, nor indeed anywhere else on the site after that time until around 500 B.C.E. It is significant that, with the construction of this defensive stronghold at the very top of the West Acropolis, the builders included a small shrine to the Great Goddess of Cyprus as a warrior. Once again, the religious predilections of the EteoCypriots led them to accompany any substantial foundation with a religious establishment. Similarly, by the 12 th century B.C.E., the sacred grove on the shoulder of the East Acropolis, Mouti tou Arvili, known as the Adonis Temenos was founded.
It is worthy of note that sometime during the 11th century B.C.E. a significant inscription on a limestone slab was created. That it was later incorporated into the base of the temenos wall of the sacred grove of Adonis may or may not be related to its initial significance. That there was also a pithos rim, dating to the 11th century B.C.E. bearing the same 3-letter inscription is suggestive.

From 2002 through 2015 the Lycoming College Expedition to Idalion excavated in a sacred precinct in the southern area of the Lower City. This cult place is situated directly north of the Late Bronze age industrial installations excavated by the Department of Antiquities. Deep soundings in the western portion of what is now referred to as 'The City Sanctuary' have revealed continuous use in that area at least from the 12th century B.C.E. through the Late Roman period, with floor after floor connected to continuously refurbished walls, the phases of which are clearly visible. (Figures 9-11) Clearly, then, from the Late Bronze Age or Proto-Geometric Period this sacred precinct served those living and working at the site of what later came to be known as Idalion.

\section{Conclusion}

When did the settlement at 'Ithal' become an urban center? Returning to this thorny question requires a return to the many definitions we have reviewed. Beginning with Cowgill's cogent criteria, there was certainly a significant occupation at Agios Sozomenos north of the Yialias River, of people doing something different from the farming communities in the surrounding territory. The existence of a copper-working settlement at Alambra Mouttes at the same time, before the beginning of the second millennium B.C.E., suggests a settlement hierarchy of the type expected in the usual core-periphery analysis of the relationship of sites to one another.

Certainly, there is evidence of pithos manufacture at Agios Sozomenos in the later Middle Cypriot period. The residents of Alambra Mouttes were working copper, and there was an extensive settlement engaged in communal activities there by around 2000 B.C.E. $[79,80]$. By the 12th century B.C.E. there was industrial activity and religious activity in more than one sanctuary at the site of later Idalion. As we have seen, most definitions of urban settlements include both socio-political and religious involvement of the population. Both elements were coalescing at Idalion no later than the 12th century B.C.E. There is at least one monumental inscription created by 1100 B.C.E. [81-89].

It would seem, then, that the settlement at Ithal, at what is now Agios Sozomenos, coalesced, possibly as an urban center, sometime around 2000 B.C.E. The center seems to have moved across the river to Idalion sometime between 1200 B.C.E. and 900 B.C.E. The indisputable evidence does tell us that the urban activity at Idalion was continuous from ca. 1200 B.C.E. through the Roman period (and beyond) [91-93]. (The second 


\section{Global Journal of Archaeology \& Anthropology}

millennium B.C.E. developments must await further excavation at Agios Sozomenos ('Ithal') and Alambra Mouttes.)

Whenever 'Ithal' became an urban center, it clearly was continuously occupied from before ca. 2000 B.C.E. onward, and arguably was growing from before, and throughout that early time. This runs directly counter to the previously held model of a rural, agrarian economy that suddenly awoke and became urban in the Late Bronze Age. If the suggestion made here is correct, that the settlement on the north side of the River Yialias was the predecessor and partner of the settlement that became Idalion on the south side of the river, then the urban development of 'Ithal;' 'Id-di-al;' 'Idalion' was continuous from ca. 2000 B.C.E. until the present day. It may be that a similar profile existed for the other inland cities at Ledra and Tamassos, suggesting that the inland, copper-producing urban centers on Cyprus developed in the third millennium, and became concentrated, perhaps at least "proto-urban" centers by ca. 2000 B.C.E.

\section{References}

1. Finley MI (1977) The Ancient City: From Fustel de Coulanges to Max Weber and Beyond. Comparative Studies in Society and History 19(3): 305-327.

2. Childe VG (1950) The Urban Revolution. Town Planning Review 21: 3-17.

3. Smith ML (2014) The Archaeology of Urban Landscapes. Annual Review of Anthropology 43: 307-323.

4. Cowgill GL (2004) Origins and Development of Urbanism: Archaeological Perspectives. In: Annual Review of Anthropology 33: 525-549.

5. Osborne R (2005) Urban Sprawl: What is Urbanization and Why Does it Matter? In Mediterranean Urbanization 800-600 BC. Mediterranean Urbanization 800-600 BC. Proceedings of the British Academy Osborne R, Cunliffe B (Eds.), Oxford University, Oxford, UK, p. 1-16.

6. Smith ME, Peregrine $P$ (2007) Form and meaning in the earliest cities: a new approach to ancient urban planning. Journal of Planning History 6: 3-47.

7. Smith ME (2012) Archaeology, Early Complex Societies, and Comparative Social Science History. In: The Comparative Archaeology of Complex Societies, Smith ME (Eds.), Cambridge University Press, Cambridge, USA, pp. 321-329.

8. Smith ME, Peregrine P (2012) Approaches to Comparative Analysis in Archaeology. In: The Comparative Archaeology of Complex Societies, Smith ME (Eds.), Cambridge, University Press, Cambridge, USA, p. 4-20.

9. Fagan BM (1997) Archaeology: A Brief Introduction, ( $6^{\text {th }}$ edn), New York, USA.

10. Wells P (1984) Farms, Villages and Cities: Commerce and Urban Origins in Late Prehistoric Europe. Ithaca, Cornell University, New York, USA.

11. Hall TD, Kardulias PN, Chase-Dunn C (2011) World-Systems Analysis and Archeology: Continuing the Dialogue. Journal of Archaeological Research 19(3): 233-79.

12. Wallerstein I (1974) The Rise and Future Demise of the World Capitalist System: Concepts for Comparative Analysis. Comparative Studies in Society and History 16(4): 387-415.

13. Peltenburg EJ (1996) From isolation to state formation in Cyprus, c 3500-1500 BC. In: The Development of the Cypriot Economy form the Prehistoric Period to the Present Day, Karageorghis V, Michaeolides D (Eds.), Lithographica, Nicosia, Cyprus, p. 11-44.
14. Gaber-Saletan P (1986) Regional Styles in Cypriote Sculpture: The Sculpture from Idalion. New York, Garland, USA.

15. Webb J, Frankel D (2013) Ambelikou Aletri Metallurgy and Pottery Production in Middle Bronze Age Cyprus. SIMA 138.

16. Porter BN (1993) Conquests or Kudurru's? A Note on Peaceful Strategies of Assyrian Government. In: The Tablet and the Scroll: Near Eastern Studies in Honor of William Hallo, Cohen ME, Snell DC, Weisberg DB, (Eds.), Bethesda, Maryland, USA.

17. Iacovou M (2007) Site Size Estimates and the Diversity Factor in Late Cypriote Settlement Histories. 348: 1-23.

18. Negbi O (2005) Urbanism on Late Bronze Age Cyprus: LC II in Retrospect. 337: 1-45

19.Arnason JP (2014) The Religio-political Nexus: Historical and Comparative Reflections. In: Religion and Politics: European and Global Perspectives, Arnason JP, Karolewski IP(Eds.), University Press, Edinburgh, Scotland, UK.

20. Chesson MS, Grahm P (2003) Tales of the City? 'Urbanism' in the Early Bronze Age Levant from the Mediterranean and Levantine Perspectives. JMA 16: 3-16.

21. Arnason JP, Raaflaub KA, Wagner P (2013) The Greek Polis and the Invention of Democracy: A Politico-cultural Transformation and Its Interpretations. The Ancient World: Comparative Histories, Mass, Blackwell, Malden, USA.

22. Bintliff J (2012) The Complete Archaeology of Greece From HunterGatherers to the $20^{\text {th }}$ Century AD. Chichester, Wiley-Blackwell, UK.

23. Bintliff J (2006) Issues in the Economic and Ecological Understanding of the Chora of the Classical Polis in its Social Context: A View from Intensive Survey Tradition of the Greek Homeland. In Surveying the Greek Chora: The Black Sea Region in a Comparative Perspective, Bilde PG, Stolba VF (Eds.), Aarhus University, Aarhus, Denmark, Europe, p. $13-26$

24. Bintliff J (1997) Regional Survey, Demography, and the Rise of Complex Societies in the Ancient Aegean: Core-periphery, neo-Malthusian, and other Interpretive Models. JFA 24(1): 1-38.

25. Rowlands M, Larsen MT, Kristiansen K (1987) Centre and Periphery in the Ancient World, Cambridge University, Cambridge, USA.

26. Ceserani G (2012) Italy's Lost Greece: Magna Graecia and the Making of Modern Archaeology. Oxford University, Oxford, UK.

27. Rupp D (1987) Vive le Roi: The Emergence of the State in Iron Age Cyprus. In Western Cyprus: Connections. An Archaeological Symposium Held at Brock University, St Catherines, Ontario, Canada, Rupp DW (Eds.), pp. 147-168.

28. Cannavò A (2010) The Cypriot Kingdoms in the Archaic Age: A Multicultural Experience in the Eastern Mediterranean." In Bolletino di Archeologia OnLine volume speciale: 2008 International Congress of Classical Archaeology Meetings between Cultures in the Ancient Mediterranean p. 37-43.

29. Fourrier S (2013) Constructing the Peripheries: Extra-Urban Sanctuaries and Peer-Polity Interaction in Iron Age Cyprus. 370: 10322.

30. Fourrier S (2002) Les territoires des royaumes chypriotes archaïques: Une esquisse de géographie historique. Cahier du Centre d'études chypriote 32: 135-146.

31.Papantoniou G (2013) Autonomous Polities at the Crossroads of Empire: The Imprint of a Transformed Islandscape in the Classical and Hellenistic Periods. BASOR 370: 169-205

32. Papantoniou G (2012) Cypriot sanctuaries and religion in the Early Iron Age: views from before and after. Cyprus and the Aegean in the Early Iron Age, Iacovou M (Eds.), Bank of Cyprus Cultural Foundation, Nicosia, pp. 285-320. 


\section{Global Journal of Archaeology \& Anthropology}

33. Hadjicosti M (1997) The Kingdom of Idalion in the Light of New Evidence. 308: 49-64.

34. Schulte-Campbell C (1989) A Late Cypriot IIC Tomb: Idalion Tomb 1.76. Introduction and Skeletal Remains." In American Expedition to Idalion, Stager L, Walker A (Eds.), Oriental Institute, Chicago, USA, pp. 119-137.

35. Ohnefalsch-Richter M (1893) Kypros, the Bible and Homer. Asher, London, UK.

36. Hadjicosti M (1999) Idalion before the Phoenicians: The Archaeological Evidence and Its Topographical Distribution. In Cyprus: The Historicity of the Geometric Horizon: Proceedings of an Archaeological Workshop, University of Cyprus, Nicosia, Iacovou M, Michaelides D (Eds.) University of Cyprus, Nicosia, Cyprus, p. 35-54.

37. Joffe A (2002) The Rise of Secondary States in the Iron Age Levant. In JESHO 45(4): 425-467.

38. Parkinson W, Galaty M (2007) Secondary States in Perspective: An Integrated Approach to State Formation in the Prehistoric Aegean." American Anthropologist 109(1): 113-29.

39. Webb J, Frankel D (2017) Marki Alonia: a long-lived Early and Middle Bronze Age settlement in the Alykos Valley. Environment, landscape and society: diachronic perspectives on settlement patterns in Cyprus, Gaber, P, Margaritis E, McCarthy A (Eds.), Nicosia, Cyprus.

40. Falconer S, Fall P (2006) Bronze Age rural ecology and village life at Tell el-Hayyat. Jordan. BAR-IS 1586.

41. Knapp AB (1993) Social Complexity: Incipience, Emergence, and Development on Prehistoric Cyprus. pp. 85-106.

42. Knapp AB (1996) Near Eastern and Aegean Texts from the Third to the First Millennia BC. Sources for the History of Cyprus II. Wallace PW, Orphanides AG, NY: Greece/Cyprus Research Center, Altamont, USA.

43. Kassianidou V, Muhly J (2012) Parallels and diversities in the production, trade and use of copper and iron in Crete and Cyprus from the Bronze Age to the Iron Age. British School at Athens Studies, Parallel Lives: Ancient Island Societies in Crete and Cyprus 20: 119140.

44. Allen J (2008) The Historical Inscription of Khnumhotep at Dahshur: Preliminary Report. BASOR 352: 29-39.

45. Satraki A (2012) Cypriot Polities in the Early Iron Age. Cyprus and the Aegean in the Early Iron Age, ed. M. Iacovou, Bank of Cyprus Cultural Foundation, Nicosia, Cyprus, pp. 261-284.

46. Webb J (2013) The Mantle of Vasilia': Have Stewart's views on the centrality of the copper trade in prehistoric Bronze Age Cyprus stood the test of time? J.R.B. Stewart: An Archaeological Legacy, Knapp AB, Webb JM, McCarthy A (Eds.), SIMA 129: 59-71.

47. Knapp AB (2013) The Archaeology of Cyprus: From Earliest Prehistory through the Bronze Age. Cambridge University, Cambridge, USA.

48. Knapp AB (2013) Revolution Within Evolution: The Emergence of a 'Secondary State' on Protohistoric Bronze Age Cyprus. Levant 45(1): $19-44$.

49. Crewe L, Hill G (2012) Finding Beer in the Archaeological Record: A Case Study from Kissonerga-Skalia on Bronze Age Cyprus. Levant. Wakefield, UK, pp. 205-237.

50. Kassianidou V (2012) Metallurgy and metalwork in Enkomi: the early phases. Eastern Mediterranean Metallurgy and Metalwork in the Second Millennium BC. A Conference in Honour of James D. Muhly, Nicosia, Kassianidou V, Papasavvas G (Eds.), Oxford and Oakville: Oxford, UK, pp. 94-106.

51. Gale N, Stos-Gale Z, Fasnacht W (1996) Metal and Metalworking. In: Alambra. A Middle Bronze Age Settlement in Cyprus: Archaeological Investigations by Cornell University, Coleman J, Barlow J, Mogelonsky
M, Schaar K, (Eds.), Studies in Archaeometallurgy, Institute for Archaeo-Metallurgical Studies, London, UK, 118: 129-142.

52. Gale N, Stos-Gale Z, Fasnacht W (1996) Copper and Copper working at Alambra. In: Alambra. A Middle Bronze Age Settlement in Cyprus: Archaeological Investigations by Cornell University, Coleman J, Barlow J, Mogelonsky M, Schaar K (Eds.), Studies in Archaeometallurgy 118: 359-426.

53. Kassianidou V (2013) The Exploitation of the Landscape: Metal Resources and the Copper Trade during the Age of the Cypriot Citykingdoms. BASOR 370: 49-82.

54. Belgiorno MR, Ferro D, Loepp D (2012) Pyrgos-Mavrorachi in Cypriot metallurgy. In: Kassianidou V, Papasavvas G (Eds.), Eastern Mediterranean Metallurgy and Metalwork in the Second Millennium BC. Oxford, UK, p. 26-34.

55. Belgiorno MR (2009) New Suggestions from Pyrgos/Mavrorachi on Cypriote 2000BC Proto Industrial Society and its Gender Perspective. In: Medelhavsmuseet Focus on the Mediterranean and Results from the Swedish Cyprus Expedition 1927-1931: A Gender Perspective p. 50-62.

56. Knapp AB (2012) Metallurgical production and trade on Bronze Age Cyprus: Views and traditions." Eastern Mediterranean Metallurgy and Metalwork in the Second Millennium BC. A Conference in Honour of James D. Muhly, Nicosia, Kassianidou V, Papasavvas G (Eds.), Oxford and Oakville: Oxbow Books, p. 14-25.

57. Iacovou M (2013) Cyprus's Political Geography in the Iron Age. 370: 30-39.

58. Iacovou M (2008) The Palaepaphos Urban Landscape Project: theoretical background and preliminary report. Report of the Department of Antiquities of Cyprus pp. 263-89.

59. Iacovou M (2012) External and Internal Migrations During the $12^{\text {th }}$ Century BC: Setting the Stage for an Economically Successful Early Iron Age. In Cyprus and the Aegean in the Early Iron Age: The Legacy of Nicolas Coldstream, Iacovou M (Eds.), Nicosia, Cyprus, pp. 207-25.

60. Radner K (2010) The stele of Sargon II of Assyria at Kition: A focus for an emerging Cypriot identity? In: Interkulturalität in der Alten Welt: Vorderasien, Hellas, Ägypten und die vielfältigen Ebenen des Kontakts, Philippika, Rollinger R, Gufler B, Lang M, Madreiter I, (Eds.), Harrassositz Verlag, Harrassositz Verlag, Wiesbaden, Germany, pp. 429-446.

61. Hill GF (1940) A History of Cyprus. Cambridge University Press, Cambridge, USA.

62. Wainwright GA (1961) Some Sea-Peoples. In JEA 47: 71-90.

63. Koucky F, Steinberg A (1982) Ancient Mining and Mineral Dressing on Cyprus. Early Pyrotechnology: the evolution of the first fire-using industries. Papers presented at a seminar on early pyrotechnology held at the Smithsonian Institution, Washington, D.C., and the National Bureau of Standards seminars on the application of the Materials and Measurement Sciences to Archaeology and Museum Conservation, organized by Franklin D, Alan and Jacqueline S Olin. Wertime TA, Wertime SF (Eds.), Smithsonian Institution, Washington DC, USA, pp. 149-180.

64. South A (2012) Tinker, tailor, farmer, miner: metal in the Late Bronze Age economy at Kalavassos." In Eastern Mediterranean Metallurgy and Metalwork in the Second Millennium BC. A Conference in Honour of James D. Muhly, Nicosia, Kassianidou V, Papasavvas G (Eds.), Oxbow Books, Oxford and Oakville, UK, p. 14-25.

65. Masson 0 (1961) Les inscriptions chypriotes syllabiques: Recueil critique et commenté. Paris. Études Chypriotes pp. 235-244.

66. Devillers B, Gaber P, Lecuyer N (2004) Notes on the Agios Sozomenos Bronze Age Settlement (Lefkosia District): Recent Palaeoenvironmental 
and Archaeological Finds. Report of the Department of Antiquities of Cyprus p. 73-85.

67. Knapp AB (1990) Ethnicity, Entrepreneurship, and Exchange: Mediterranean Inter-Island Relations in the Late Bronze Age. BSA 85: 115-53.

68. Weiss H (2015) Megadrought, collapse, and resilience in late 3rd millennium BC Mesopotamia. 2200 BC - Ein Klimasturz als Ursache für den Zerfall der Alten Welt? 2200 BC A climatic breakdown as a cause for the collapse of the old world. University of Barcelona. Berlin, Germany.

69. Kearns C (2013) Paleoenvironmental evidence for late Holocene dynamics: Carbon stable isotope analysis on archaeological charcoal. Cornell University, New York, USA.

70. Brown M, Devillers B (2017) Environmental Change and State-Leve Agency in Protohistoric Cyprus: Infilling of the Yialias Ria. Environment, landscape and society: diachronic perspectives on settlement patterns in Cyprus. Gaber P, Margaritis E, McCarthy A (Eds.), (forthcoming).

71. Pilides D (2017) Source: Department of Antiquities. Republic of Cyprus, Cyprus.

72. Gaber P (2008) The History of History: Excavations at Idalion and the Changing History of a City Kingdom. NEA 71(1-2): 52-63.

73. Gaber P (2017) Idalion III: Excavations on the Terrace of the East Acropolis, Mouti-tou-Arvili and SpecialStudies. Boston, USA.

74. Gaber P (1995) The History of Ancient Idalion in the Light of Recent Excavations. In: Visitors, Immigrants, and Invader in Cyprus, Wallace $P$ (Eds.), State University of New York at Albany, Albany, New York, USA p. 32-39.

75. Gaber P, Bazemore GB (1999) Two Enigmatic Inscriptions from Idalion. In Report of the Department of Antiquities of Cyprus pp. 237-242.

76. Gaber P, Dever WG (1996) Idalion, Cyprus: Conquest and Continuity. AASOR pp. 81-127.

77. Karageorghis V (2003) Excavations at Kition: Volume V, The Phoenician and Later Levels. Department of Antiquities, Nicosia, Cyprus.

78. Marvin M (1974) History of the Site of Idalion. In: American Expedition to Idalion, Cyprus, First Preliminary Report: Seasons of 1971 and 1972, Stager L, Walker A, Wright GE (Eds.), Cambridge, USA.

79. Coleman JE, Barlow JA, Magelonsky K, Schaar K (1996) Alambra: A Middle Bronze Age Settlement in Cyprus: Archaeological Investigations by Cornell University pp. 1974-1985.

This work is licensed under Creative Commons Attribution 4.0 License DOI: 10.19080/GJAA. 2018.05.555680
80. Barlow JA (1982) The Stratified Pottery of the Bronze Age Settlement at Alambra, Cyprus: A Preliminary Report. Doctoral Dissertation; Cornell University, New York, USA.

81. Pilides D (2014) The new excavations at Agios Sozomenos in central Cyprus.

82. Boëthius A (1948) Ancient Town Architecture and the New Material from Olynthus. AJP. 69(4): 396-407.

83. Crewe L (2007) Early Enkomi: Regionalism, Trade and Society at the Beginning of the Late Bronze Age on Cyprus.BAR-IS, Archaeopress. Oxford, UK.

84. Düring B (2016) Excavations at Chlorakas Palloures. Report of the Department of Antiquities of Cyprus, (forthcoming).

85. Fourrier S (2007) La coroplastic chypriote archaique: Identités politiques à l'époque des royaumes. Travaux de la Maison de l'Orient et de la Méditerranée 46. Lyon: Maison de l’Orient et de la Méditerranée -Jean Pouilloux.

86. Fuller B, Romer P (2012) Successes and the City: How Charter Cities Could Transform the Developing World. Macdonald-Laurier Institute for Public Policy. Fustel de Coulanges. 1864. La Cité Antique: Étude sur le culte, le droit, les institutions de la Grèce et de Rome, Paris, France.

87. Koucky F, Steinberg A (1982a) The Ancient Slags of Cyprus. Early Metallurgy in Cyprus, $4000-500$ B.C. Acta of the International Symposium, Larnaca, Cyprus, pp. 117-141.

88. Kyriakides E (2007) The Archaeology of Ritual. Cotsen Advanced Seminars, Los Angeles, USA.

89. Overbeck J, Swiny S (1972) Two Bronze Age Sites at Kafkalla (Dhali) SIMA xx. 4, xxiii. Gothenburg.

90. Renfrew C (1994) Concluding Remarks: Childe and the Study of Culture Process. In: The Archaeology of V. Gordon Childe: Contemporary Perspectives, Harris DR (Eds.), University College of London Press, London, Uk, pp. 121-133.

91. Smith ME, Peregrine P (2009) V. Gordon Childe and the urban revolution: an historical perspective on a revolution in urban studies. Town Planning Review 80: 3-29.

92. Stein GJ (2002) From Passive Periphery to Active Agents: Emerging Perspectives. In the Archaeology of Interregional Interaction: Archeology Division Distinguished Lecture AAA Annual Meeting. American Anthropologist 104(3): 903-916.

93. Weber M (1958) The City. Trans. D. Martindale and G. Neuwirth from German. Free Press, New York, USA.

\section{Your next submission with Juniper Publishers will reach you the below assets}

- Quality Editorial service

- Swift Peer Review

- Reprints availability

- E-prints Service

- Manuscript Podcast for convenient understanding

- Global attainment for your research

- Manuscript accessibility in different formats

(Pdf, E-pub, Full Text, Audio)

- Unceasing customer service

Track the below URL for one-step submission https://juniperpublishers.com/online-submission.php 